\title{
Tükenme Egzersizi Yaptırılan Ratlarda Kurkumin Takviyesi: Antioksidan Parametreler ve Laktat Düzeyleri
}

\author{
Dr. Taner YILMAZ \\ Doç. Dr. Alparslan ÜNVEREN
}




\title{
(C) Copyright 2020
}

Bu kitabın, basım, yayın ve satış hakları Akademisyen Kitabevi A.Ş.'ne aittir. Anılan kuruluşun izni alınmadan kitabın tümü ya da bölümleri mekanik, elektronik, fotokopi, manyetik kağıt ve/veya başka yöntemlerle çoğaltılamaz, basılamaz, dağıtılamaz. Tablo, şekil ve grafikler izin alınmadan, ticari amaçh kullanılamaz. Bu kitap T.C. Kültür Bakanlı̆̆ bandrolü ile satılmaktadır.

\section{ISBN}

978-625-710-623-8

\section{Kitap Adı}

Tükenme Egzersizi Yaptırılan Ratlarda Kurkumin Takviyesi:

Antioksidan Parametreler ve Laktat Düzeyleri

\author{
Yazarlar \\ Taner YILMAZ \\ Alparslan ÜNVEREN \\ Yayın Koordinatörü \\ Yasin Dilmen \\ Sayfa ve Kapak Tasarımı \\ Akademisyen Dizgi Ünitesi
}

Yayıncı Sertifika No

47518

Baskı ve Cilt

Sonçağ Matbaacılık

Bisac Code

SPO000000

\section{GENEL DAĞITIM}

\section{Akademisyen Kitabevi A.Ş.}

Halk Sokak 5 / A

Yenişehir / Ankara

Tel: o312 4311633

siparis@akademisyen.com

\section{www . a kade misyen.com}




\section{TEŞEKKÜR}

Tez çalışma sürecinde bilgi ve tecrübesi ile bana yol gösteren ve destekleyen tez danışmanım Sayın Yrd. Doç.Dr. Alparslan ÜNVEREN'e,

Tez çalışmamda göstermiş oldukları katkı ve desteklerinden dolayı Sayın Doç.Dr. Mustafa AKIL’ a, Yrd. Doç.Dr. Funda Karabağ ÇOBAN' a ve Ar. Gör. Dr. Meryem SAVAŞLI GÜLAÇ 'a teşekkür ederim.

Bu tez Dumlupınar Üniversitesi Bilimsel Araştırma Projeleri birimi tarafından 2015-60 proje numarası ile desteklenmiştir. 


\section{SiMGELER ve KISALTMALAR DİİNi}

AMPK : $\quad$ Activated Protein Kinase

ATP : $\quad$ Adenozin Trifosfat

BHA : Butillendirilmiş Hidroksianisol

BHT : $\quad$ Butillendirilmiş Hidroksitoluen

CAT: Katalaz

CD: Konjüge Dienler

Cİs: Cisplatin

CK : $\quad$ Kreatin Kinaz

CoQ10: Koenzim Q10

Cu: Bakır

CUR: $\quad$ Kurkumin

DMSO: $\quad$ Dimetil Sülfoksit

DNA: Deoksirübo Nükleik Asit

EDTA: $\quad$ Etilendiamin Tetraasetik Asit

Fe: Demir

FRAP: $\quad$ Ferric Plazma Yeteneği Azaltılması

GPx: Glutatyon Peroksidaz 

GR:
Gryphon
GSH:
Glutatyon
GSH-Px: Glutatyon Peroksidaz
GSH-Red: Glutatyon Redüktaz
GSH-Tr: Glutatyon Transferaz
GSSG: $\quad$ Okside Edilmiş Glutatyon
$\mathrm{H}_{2} \mathrm{O}_{2}$ : Hidrojen Peroksit Radikali
HCl: Hidrojen Klorür
HİV: $\quad$ İnsan İmmün Sistem Yetersizliği
İP: IIntraperionetal
LDL: $\quad$ Düşük Yoğunluklu Lipoprotein
LOOH: $\quad$ Lipid Hidroperoksitler
MAPK: $\quad$ Mitojen Akitive Protein Kinazlar
MDA: Malondialdehit
Mn: $\quad$ Manganez
Mn-SOD: $\quad$ İçeriğinde Manganez (Mn) İçeren Süperoksit dismutaz
NAC : $\quad \mathrm{N}$-asetilsistein
NADPH: Nikotinamid Adenin Dinükleotid Fosfat
NF $\kappa B$ : $\quad$ Nükleer Faktör Aktivasyonu
NO: $\quad$ Nitrik Oksit
$\mathrm{O}_{2}^{-}$: $\quad$ Superoksit Anyon Radikali
$\mathrm{O}_{2}$ : $\quad$ Singlet Oksijen Radikali
${ }^{\circ} \mathrm{C}: \quad$ Santigrat Derece
OCI-: $\quad$ Hipoklorit İyonu
OH: $\quad$ Hidroksil Radikali 
-OOCR: Alkilperoksil Radikali

ORAC : Oksijen Radikal Absorbans Kapasitesi

oxLDL : Okside Olmuş Düşük Yoğunluklu Lipoprotein

PC: $\quad$ Fosfetidilkolin

POD: $\quad$ Peroksidaz

ROS: $\quad$ Reaktif Oxygen Species

ROT: $\quad$ Reaktif Oksijen Türleri

-SH : $\quad$ Sülfhidril

Sit O: $\quad$ Sitokrom Oksidaz

SOD: $\quad$ Süperoksit Dismutaz

TAS : $\quad$ Total Antioksidan Durumu

TBA: $\quad$ Tiyobarbiturik Asit Değeri

TBARS : $\quad$ Tiobarbitürik Asit

TEAC : $\quad$ Eşdeğer Antioksidan Kapasitesi

TG: $\quad$ Trigliserit

TGSH : $\quad$ Toplam Glutatyon Konsantrasyonu

TRAP : $\quad$ Toplam Radikal Trapping Antioksidan Parametresi

UV: $\quad$ Ultra Viyole

$\mathrm{VO}_{2}$ : Oksijen Tüketimi

VO2max: Maksimum Oksijen Kullanımı

Zn-SOD: İçeriğinde (Zn) İçeren Süperoksitdismutaz

>: $\quad$ Büyüktür

$\leq: \quad$ Küçük Eşit

8-OHdG: $\quad$ DNA Oksidatif Hasar1 


\section{İÇINNDEKİLER}

\section{BÖLÜM I}

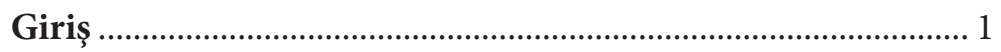

1.1. Araştırmanın Önemi............................................................. 4

1.2. Araştırmanın Amac1 ................................................................. 5

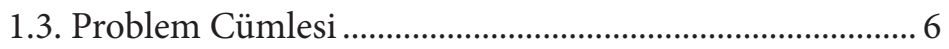

1.3.1. Alt Problemler ............................................................. 7

1.4. Hipotezler ............................................................................. 7

1.5. Araştırmanın Varsayımları..................................................... 8

1.6. Araştırmanın Sinırlılıkları................................................... 8

\section{BÖLÜM II}

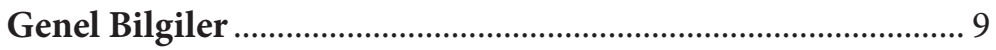

2.1. Kurkumin Nedir? ............................................................. 9

2.1.1. Kurkuminin Kimyasal Özelliği ............................... 10

2.1.2. Kurkuminin Moleküler Yapısı................................... 11

2.1.3. Kurkuminin Metabolizmas1 ........................................ 11

2.1.4. Kurkuminin Biyolojik Etkileri ................................... 12

2.1.5. Turmerik/Kurkuminin Biyolojik Özellikleri........... 13

2.1.6. Kurkuminin Antioksidan ve Antiinflamatuvar

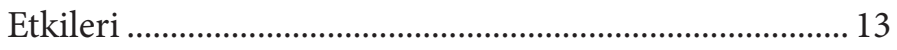

2.1.7. Kurkuminin Yara İyileşmesi Üzerine Etkileri ........ 14

2.1.8. Kurkuminin Angiogenezisi Düzenleyici Etkisi ..... 15

2.1.9. Kurkuminin Antikanser Etkisi................................. 15

2.1.10. Kurkuminin Antimikrobiyal Etkisi ....................... 16 
2.2. Serbest Radikaller Ve Oksidatif Stres............................... 16

2.3. Antioksidan Mekanizma ................................................. 19

2.3.1. Hücre İçi Antioksidan Savunma Sistemleri ............ 22

2.3.1.1. Süperoksit Dismutaz (SOD); ............................ 22

2.3.1.2. Katalaz (CAT);.................................................... 22

2.3.1.3. Glutatyon (GSH);............................................ 23

2.3.1.4. Glutatyon Peroksidaz (GSH-Px); ..................... 24

2.3.1.5. Sitokrom Oksidaz (Sit O);................................ 26

2.3.2. Hücre D1şı Antioksidan Savunma Sistemleri......... 26

2.3.2.1. Askorbik asit; ....................................................... 26

2.3.2.2. E vitamini; ........................................................... 27

2.3.2.3. Retinoitler; ............................................................ 27

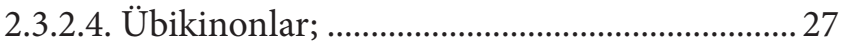

2.3.2.5. Flavonoitler; ......................................................... 28

2.3.2.6. Melatonin; .............................................................. 28

2.3.2.7. Ürik asit; ............................................................... 29

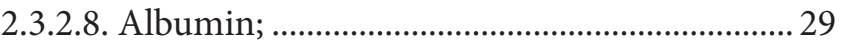

2.3.2.9. Diğer Antioksidan Kaynaklar;.......................... 29

2.4. Antioksidan Savunma Sistemi ve Egzersiz İlişkisi .......... 30

2.5. Akut Egzersiz ve Oksidatif Stres İlişkisi ............................ 34

2.6. Akut Egzersiz Protokolleri ve Lipid Peroksidasyonu..... 41

2.7. Glutatyon ve Egzersiz İlişkisi ............................................ 42

2.8. Antioksidan Kapasite ve Egzersiz İlişkisi ......................... 43

2.9. Antioksidan Takviyeler ve Egzersiz İlişkisi ...................... 44

2.10. Reaktif Oksijen Türleri İle İlgili Egzersiz Çalışmaları . 46

2.11. Farklı Egzersiz Çalışmaları Ve Oksidatif Stres İlişkisi. 51

\section{BÖLÜM III}

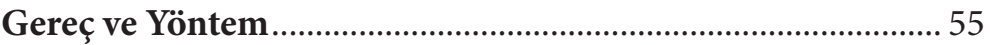

3.1. Etik Kurul Onayı................................................................. 55

3.2. Deney Hayvanlarının Temini ve Bakımı.......................... 55 


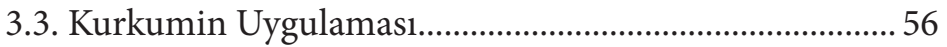

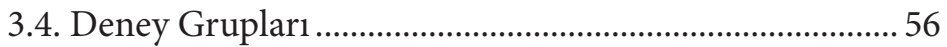

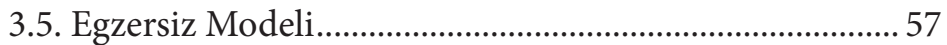

3.6. Kan ve Örneklerin Temini................................................. 57

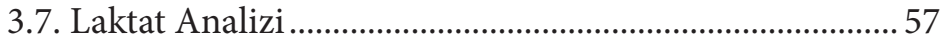

3.8. Biyokimyasal Ölçüm Yöntemleri......................................... 58

3.8.1. Doku Homojenizasyonu ............................................. 58

3.8.2. Doku Homojenatlarından Total Protein Analizi... 58

3.8.3. Hemolizat Hemoglobin Tayini................................... 59

3.8.4. Süperoksid Dismutaz Akivitesinin Tayini ............... 59

3.8.5. Katalaz Aktivite Tayini ................................................ 59

3.8.6. MDA Aktivite Tayini ................................................... 60

3.8.7. Redükte Glutatyon (GSH) Tayini .............................. 60

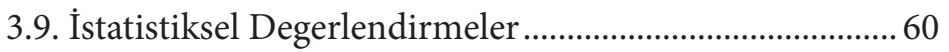

\section{BÖLÜM IV}

Bulgular 61

\section{BÖLÜM V}

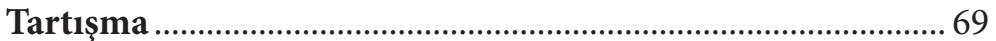

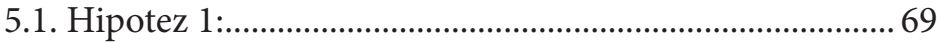

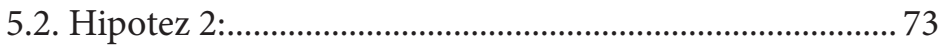

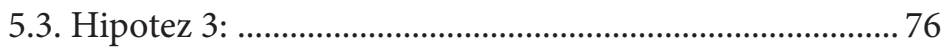

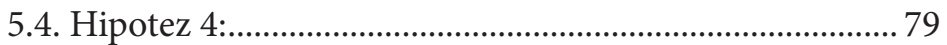

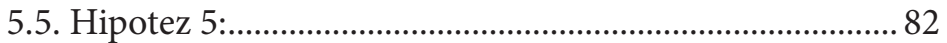

\section{BÖLÜM VI}

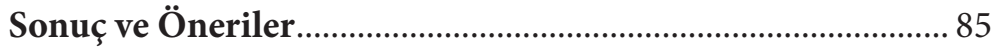

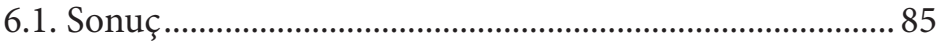




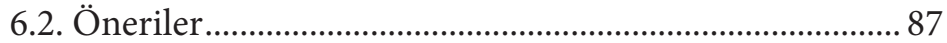

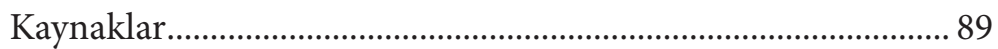

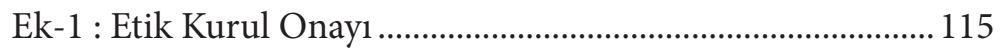

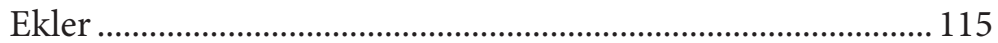




\section{KAYNAKLAR}

1. Abed, K.E., Rebai, H., Bloomer, R.J., Trabelsi, K., Masmoudi, L., Zbidi, A., Sahnoun, Z., Hakim, A., Tabka, Z. (2011). Antioksidant status and oksidative stres at rest and in response to acute exercise in judokas and sedantary men. Journal of Strength \& Conditioning Research, 25(9):2400-2409.

2. Aggarwal, B.B., Sethi, G., Ahn, K.S., Sandur, S.K., Pandey, M.K., Kunnumakkara, A.B., Sung, B., Ichikawa, H. (2006). Targeting signal transducer and activator of transcription 3 for prevention and therapy of cancer: modern target but ancient solution. Ann. Y. Acad. Sci. 1091, 151-169.

3. Aguilo, A., Tauler, P., Fuentespina, E., Tur, J.A., Cordova, A., Pons, A. (2005). Antioxidant response to oxidative stress induced by exhaustive exercise. Physiol Behav, 84(1),1-7.

4. Aguilo, A., Tauler, P., Pilar Guix, M., Villa, G., Cordova, A., Tur, J.A., Pons, A. (2003). Effect of exercise intensity and training on antioxidants and cholesterol profile in cyclists. The Journal of Nutritional Biochemistry, 14: 319-325.Akıl, M. (2011).

5. M. Akil, U. Gurbuz, M. Bicer, A. Sivrikaya, R. Mogulkoc, A.K. Baltaci. Effect of selenium supplementation on lipid peroxidation, antioxidant enzymes, and lactate levels in rats immediately after acute swimming exercise. Biol Trace Elem Res. 2011; 142: 651-659.

6. Akkuş, İ. (1995). Serbest Radikaller ve Fizyopatolojik Etkileri. 1.Bask1, Konya, Mimoza Yayınları, 1-75.

7. Akova, B., Surmen-Gur. E., Gur, H., Dirican, M., Sarandol, E., Kucukoglu, S. (2001). Exercise induced oxidative stress and muscle performance in healthy women: role of vitamin E supplementation and endogenous oestradiol. Eur. J. Appl. Physiol, 84(1-2),141-147.

8. Alessio, H.M., Goldfarb, A.H., Cao, G. (1997). Exercise induced oxidative stress before and after vitamin $\mathrm{C}$ supplementation. Int. J. Sport. Nutr.,7(1),1-9. 
9. Alessio, H.M., Hagerman, A.E., Fulkerson, B.K., Ambrose, J., Rice, R.E,. Wiley, R.L. (2000). Generation of reactive oxygen species after exhaustive aerobic and isometric exercise. Med. Sci. Sports Exerc., 32(9), 1576-1581.

10. Allen, R.G., Tresini, M. (2000). Oxidative stress and gene regulation. Free Radic Biol Med, 28(3),463-499.

11. Al-Rubaei, Z.M., Mohammad, T.U., Ali, L.K. (2014). Effects of local curcumin on oxidative stress and total antioxidant capacity in vivo study. Pak. J. Biol. Sci., 17(12):1237-41.

12. Aoshima, S., Fujisawa, S., Kolsayashi, A. (1993). Changes in the sub-cellular distribution of free carnitine and its acyl derivativesin diabetic rat hearts following treatment with 1-carnitine. Jpn Heart J, 34, 763- 72.

13. Ascensao, A., Ferreira, R., Marques, F., Oliveira, E., Azevedo, V., Soares, J., Magalhaes, J. (2007). Effect of off-road competitive motocross race on plasma oxidative stress and damage markers. $\mathrm{Br} \mathrm{J}$ Sports Med, 41(2),101-105.

14. Aslan. R., Şekeroğlu, M.R., Tarakçığlu, M., Bayıroğlu, F., Meral, İ. (1998). Effect of acute and regular exercise on antioxidative enzymes, tissue damage markers and membran lipid peroxidation of erythrocytes in sedentary students. J. Med.Sci., 28, 411-4.

15. Aydin, A., Sayal, A., Isımer, A. (2001). Serbest radikaller ve antioksidan savunma sistemi. Ankara Gülhane Askeri Tip Akademisi Bastmevi, 20: 48.

16. Babu. P. S., Srinivasan. K. (1997). Hypolipidemic action of curcumin, the active principle of turmeric (curcuma longa) in streptozotocin induced diabetic rats. Mol Cell Biochem., 166, 169-175.

17. Bailey, D.M., Lawrenson, L., McEneny, J., Young, I.S., James, P.E., Jackson, S.K., Henry, R.R., Mathieu-Costello, O., McCord, J.M., Richardson, R.S. (2007). Electron paramagnetic spectroscopic evidence of exerciseinduced free radical accumulation in human skeletal muscle. Free Radic Res, 41(2),182-190.

18. Bailey, D.M., Young, I.S., McEneny, J., Lawrenson, L., Kim, J., Barden, J., Richardson, R.S. (2004). Regulation of free radical outflow from an isolated muscle bed in exercising humans. Am. J. Physiol Heart Circ Physiol, 287(4),1689-99.

19. Bast, A., Haenen, G.R.M., Doelman, C.J.A. (1991). Oxidants and Antioxidants. American Journal of Medicine, 91: 2-13.

20. Bayat, Z. (2013). Hepatik İskemi Reperfüzyon Hasarında Beta Glukan ve Morinda Citrifolia l'nin Koruyucu Etkilerinin Araştırılması. 
Yüksek Lisans tezi, Kahramanmaraş Sütçü İmam Üniversitesi, Kahramanmaraş.

21. Belviranlı, M., Okudan, N., Esra, K., Atalık, N. (2012). Yaşlı sıçanlarda kurkumin takviyesinin kalp dokusunun oksidan/antioksidan durumu üzerine etkileri. Genel Tip Dergisi, 22(2):61-66.

22. Bengmark, S., Mesa, M.D., Gil, A. (May-Jun 2009). Plant-derived health: the effects of turmeric and curcuminoids. Nutr. Hosp., 24(3), 273-81.

23. Beutler, E. (1984). Red cell Metabolism 3rd. Ed., Orlando:Grune and Stratton.

24. Beyer, C.E., Steketee, J.D., Saphier, D. (1998). Antioxidant properties of melatonin, An emerging mystery, Biochemical Pharmacology, Vol.56, 1265-1272.

25. Biçer, M., Günay M., Baltaci, A.K., Üney, K., Mogulkoc R., Akil, M. (2012). Effect of zinc supplementation on lipid peroxidation and lactate levels in rats with diabetes induced by streptozotocin and subjected to acute swimming exercise. Bratisl Lek Listy 2012; 113 (4):199-205.

26. Biswas, S.K., McClure, D., Jimenez, L.A., Megson, I.L., Rahman, I. (2005). Curcumin induces glutathione biosynthesis and inhibits NF-kappaB activation and interleukin- 8 release in alveolar epithelial cells: mechanism of free radical scavenging activity. Antioxid Redox Signal, 7: 32-41.

27. Bjelakovic, G., Nikolova, D., Gluud, L.L., Simonetti, R.G., Gluud, C. (2007). Mortality in randomized trials of antioxidant supplements for primary and secondary prevention: systematic review and meta analysis. JAMA , 297 (8), 842-857.

28. Bloomer, R.J. (2005). Energy cost of moderate duration resistance and aerobic exercise. J. Strength Cond Res. 2005, 19(4), 878-882.

29. Bloomer, R.J., Davis, P.G., Consitt, L.A., Wideman, L. (2007). Plasma protein carbonyl response to increasing exercise duration in aerobically trained men and women. Int J Sports Med., 28(1),21-25.

30. Bloomer, R.J., Falvo, M.J., Fry, A.C., Schilling, B.K., Smith, W.A., Moore, C.A. (2006). Oxidative stress response in trained men following repeated squats or sprints. Med. Sci. Sports Exerc.,38(8),1436-1442.

31. Bloomer, R.J., Falvo, M.J., Schilling, B.K., Smith, W.A. (2007). Prior exercise and antioxidant supplementation: effect on oxidative stress and muscle injury. J. Int. Soc. Sports Nutr., 4,9.

32. Bloomer, R.J., Fry, A.C., Falvo, M.J., Moore, C.A. (2007). Protein carbonyls are acutely elevated following single set anaerobic exercise in resistance trained men. J. Sci. Med. Sport., 10(6),411-417. 
33. Bloomer, R.J., Goldfarb, A.H. (2004). Anaerobic exercise and oxidative stress: a review. Can J. Appl Physiol, 29(3),245-263.

34. Bloomer, R.J., Goldfarb, A.H., McKenzie, M.J. (2006). Oxidative stress response to aerobic exercise: comparison of antioxidant supplements. Med. Sci. Sports Exerc., 38(6),1098-1105.

35. Bloomer, R.J., Goldfarb, A.H., Wideman, L., McKenzie, M.J., Consitt, L.A. (2005). Effects of acute aerobic and anaerobic exercise on blood markers of oxidative stress. J. Strength Cond. Res., 19(2),276285.

36. Boadi, W.Y., Iyere, P.A., Adunyah, S.E. (2005). In vitro exposure to quercetin and genistein alters lipit peroxides and prevents the loss of glutatione in human progenitor mononuclear (U937) cells. J. Appl Toxicol; 25: 82-88.

37. Bogdan, C., Rollinghoff, M., Diefenbach, A. (2000). Reactive oxygen and reactive nitrogen intermediates in innate and specific immunity. Curr Opin Immunol, 12(1),64-76.

38. Boyalı, E. (2009). E Vitamini Uygulamasının Akut Teakwondo Egzersizinde Lipid Peroksidasyonu, Antioksidan Enzimler ve Laktat Düzeylerine Etkisi. Doktora tezi, Selçuk Üniversitesi, Konya.

39. Braun, B., Clarkson, P.M., Freedson, P.S., Kohl, R.L. (1991). Effects of coenzyme Q10 supplementation on exercise performance, VO2 max, and lipid peroxidation in trained cyclists. Int. J. Sport Nutr., 1(4),353-365.

40. Brezezinska-Slebodzinska, E. (2001). Erythrocyte Osmotic fragility test as the measure of defence against free radicals in rabbits of different age. Acta Veterinerica Hungarica, 49(4), 413-419.

41. Brooks, G.A. (1985). Anaerobic threshold: review of the concept and directions for future research". Med. Sci. Sports Exerc., 17(1): 22-31.

42. Bryant, R.J., Ryder, J., Martino, P., Kim, J., Craig, B.W. (2003). Effects of vitamin $\mathrm{E}$ and $\mathrm{C}$ supplementation either alone or in combination on exercise-induced lipid peroxidation in trained cyclists. J. Strength Cond. Res., 17(4),792-800.

43. Bryer, S.C., Goldfarb, A.H. (2006). Effect of high dose vitamin C supplementation on muscle soreness, damage, function, and oxidative stress to eccentric exercise. Int. J. Sport Nutr Exerc. Metab, 16(3),270-280.

44. Burke, T.M., Wolin, M.S. (1987). Hydrogen peroxide elicits pulmonary arterial relaxation and guanylate cyclase activation. Am J Physiol, 252 (4 Pt 2):H721-32. 
45. Burneikoa, R.C.M., Diniz, Y.S., Galhardib, C.M., Rodriguesb, H.G., Ebaida, G.M.X., Fainea, L.A., Padovanib, C.R., Cicognab, A.C., Novellia, E.L.B. (2006). Interaction of hypercaloric diet and physical exercise on lipid profile, oxidative stress and antioxidant defenses. Food and Chemical Toxicology, 44: 1167-1172.

46. Calabrese, V., Butterfield, D.A., Stella, A.M (2003). Nutritional antioxidants and the heme oxygenase pathway of stres tolerance: novel targets for neuroprotection in Alzheimer's disease. Ital J. Biochem, 52 (4), 177-181.

47. Camus, G., Felekidis, A., Pincemail, J., Deby-Dupont, G., Deby, C., Juchmes- Ferir, A., Lejeune, R., Lamy, M. (1994). Blood levels of reduced/oxidized glutathione and plasma concentration of ascorbic acid during eccentric and concentric exercises of similar energy cost. Arch Int. Physiol Biochim Biophys, 102(1),67-70.

48. Chang, C.K., Tseng, H.F., Hsuuw, Y.D., Chan, W.H., Shieh, L.C. (2002). Higher LDL oxidation at rest and after a rugby game in weekend warriors. Ann Nutr Metab, 46(3-4),103-107.

49. Chatzinikolaou, A.I., Draganidis, D., Avloniti, A., Karipidis, A., Jamurtas, A.Z., Skevaki, C.L., Tsoukas, $\mathrm{D}_{.}$, Sovatzidis, A., Theodorou, A., Kambas, A., Papassotiriou, I., Taxildaris, K., Fatouros, I. (2014). The microcycle of inflammation and performance changes after a basketball match. J Sports Sci., 32(9):870-82.

50. Chevion, S., Moran, D.S., Heled, Y., Shani, Y., Regev, G., Abbou, B., Berenshtein, E., Stadtman, E.R., Epstein, Y. (2003). Plasma antioxidant status and cell injury after severe physical exercise. Proc. Natl. Acad. Sci. USA., 100(9),5119-5123.

51. Child, R., Brown, S., Day, S., Donnelly, A., Roper, H., Saxton, J. (1999). Changes in indices of antioxidant status, lipid peroxidation and inflammation in human skeletal muscle after eccentric muscle actions. Clin. Sci. (Lond), 96(1),105-115.

52. Child, R.B., Wilkinson, D.M., Fallovvfield, J.L., Donnelly, A.E. (1998). Eleveted serum antioxidant capacity and plasma malondialdehyde concentration in respons to a simulated halfmarathon. Rua Med. Sci. Sports Exerc., 30, 1603-1607.

53. Child, R.B., Wilkinson, D.M., Fallowfield, J.L. (2000). Effects of a training taper on tissue damage indices, serum antioxidant capacity and half-marathon running performance. Int. J. Sports Med., 21(5),325-331.

54. Chung, H.Y., Cesari, M., Anton, S., Marzetti, E., Giovannini, S., Seo, A.Y., Carter, C., Yu, B.P., Leeuwenburgh, C. (2008). Molecular inf- 
lammation: Underpinnings of aging and age-related diseases. Ageing Res. Rev.

55. Ciardi, C., Jenny, M., Tschoner, A., Ueberall, F., Patsch, J., Pedrini, M., Ebenbichler, C., Fuchs, D. (2012). Food additives such as sodium sulphite, sodium benzoate and curcumin inhibit leptin release in lipopolysaccharide-treated murine adipocytes in vitro. Brit. J. Nutr., 107, 826-833.

56. Clarkson, P.M. (1995). Antioxidants and physical performance. Critical Reviews in Food Science and Nutrition, 35: 131-141.

57. Cooper, C.E., Vollaard, N.B.J., Choueiri, T., Wilson, M.T. (2002). Exercise, free radicals and oxidative stress. Biochem Soc. Trans., 30, 280-5.

58. Coşkun, S., Gonul, B., Guzel, N.A., Balabanll, B. (2005). The effects of vitamin $\mathrm{c}$ supplementation on oxidative stress and antioxidant content in the brains of chronically exercised rats. Mol. Cell Biochem, 280, 135-8.

59. Crane, F.L. (2001). Biochemical functions of coenzyme Q10. J. Am Coll Nutr, 20(6),591-598.

60. Çavdar, C., Sifil, A., Çamsarı, T. (1997). Reaktif Oksijen Partikülleri ve Antioksidan Savunma. Türk Nefroloji Diyaliz ve Transplantasyon Dergisi, 3-4: 92-95.

61. Çimen, C., Oter, C., Demir, H., Savran, A. (2005). Rat Eritrositlerinden Elde Edilen Katalaz Enziminin Karekterizasyonu ve Kinetiğinin İncelenmesi. Yüzüncü Yll Üniversitesi, Veterinerlik Fakültesi Dergisi, 16 (1), 15-20.

62. Çolakoğlu, S., Kırkalı, G., Çolakoğlu, M., Örmen, M., Akan, P. (1998). Egzersizde E Vitamini Desteğinin Oksidan Stres ve Dayanıklılık Üzerine Etkileri. Klinik Gelişim, 11, 412-22.

63. Dağlıŏlu, Ö. (2009). Elit Yüzücülerde ve Sedanterlerde Aerobik ve Anaerobik Egzersizin Oksidatif Stres Üzerine Etkisi ve Pon1 Gen Polimorfizminin Araştırılması. Doktora tezi, Marmara Üniversitesi, İstanbul.

64. Dalle-Donne, I., Rossi, R., Colombo, R., Giustarini, D., Milzani, A. (2006). Biomarkers of oxidative damage in human disease. Clin Chem., 52(4),601-623.

65. Davies, K.J., Quintanilha, A.T., Brooks, G.A., Packer, L. (1982). Free radicals and tissue damage produced by exercise. Biochem Biophys Res. Commun, 107(4),1198-1205.

66. Davison, G., Gleeson, M., Phillips, S. (2007). Antioxidant supplementation and immunoendocrine responses to prolonged exercise. Med Sci Sports Exerc., 39(4), 645-652. 
67. Dawson, B., Henry, G.J., Goodman, C., Gillam, I., Beilby, J.R., Ching, S., Fabian, V., Dasig, D., Morling, P., Kakulus, B.A. (2002). Effect of vitamin $\mathrm{C}$ and $\mathrm{E}$ supplementation on biochemical and ultrastructural indices of muscle damage after a $21 \mathrm{~km}$ run. Int. J. Sports Med., 23(1),10-15.

68. Dawson, C.A., Horvarth, S.M. (1970). Swimming in small laboratory animals. Medicine and Science in Sports, 2, 51-78.

69. Di Massimo, C., Scarpelli, P., Tozzi-Ciancarelli, M.G. (2004). Possible involvement of oxidative stress in exercise-mediated platelet activation. Clin Hemorheol Microcirc, 30(3-4), 313-316.

70. Dillard, C.J., Litov, R.E., Savin, W.M., Dumelin, E.E., Tappel, A.L. (1978). Effects of exercise, vitamin E, and ozone on pulmonary function and lipid peroxidation. J. Appl Physiol, 45(6),927-932.

71. Dousset, E., Steinberg, J.G., Faucher, M., Jammes, Y. (2002). Acute hypoxemia does not increase the oxidative stress in resting and contracting muscle in humans. Free Radic Res, 36(6), 701-704.

72. Draper, H.H., Hadley, M. (1990). Malondialdehyde determination as index of lipid peroxidation. Methods Enzymol 186, 421-30.

73. Droge, W. (2002). Free radicals in the physiological control of cell function. Physiol Rev., 82(1), 47-95.

74. Duthie, G.G., Robertson, J.D., Maughan, R.J., Morrice, P.C. (1990). Blood antioxidant status and erythrocyte lipid peroxidation following distance running. Arch Biochem Biophys, 282(1), 78-83.

75. El-Demerdash, F.M., Yousef, M.I., Kedwany, F.S., Baghdadi, H.H. (2004). Cadmium-induced changes in lipid peroxidation, blood hematology, biochemical parameters and semen quality of male rats: protective role of vitamin E and beta-carotene. Food Chem Toxicol, 42(10), 1563-71.

76. Elosua, R., Molina, L., Fito, M., Arquer, A., Sanchez-Quesada, J.L., Covas, M.I., Ordonez-Llanos, J., Marrugat, J. (2003). Response of oxidative stress biomarkers to a 16-week aerobic physical activity program, and to acute physical activity, in healthy young men and women. Atherosclerosis, 167(2),327-334.

77. Emre, M.H., Düzova, H., Sancak, B., Polat, A., Erdoğan, H., Yoloğlu, S. (2004). Serum selenium response to maximal anaerobic exercise among sportsmen trained at various levels. J. Trace Elem. Exp. Med,17, 93-100.

78. Evans, J.L., Goldfine, I.D., Maddux, B.A., Grodsky, G.M. (2003). Are Oxidative Stres Activated Signaling Pathways Mediators of insülin Resistance and Cell Dysfunction. Diabetes, 52, 1-8. 
79. Fairbanks, V.F., Klee, G.G., Biochemical aspects of hematology. In: Tietz N.W., (ed) Textbook of clinical chemistry. Philadelphia, PA: WB Saunders.

80. Fang, Y.Z., Yang, S., Wu, G. (2002). Free radicals, antioxidants and nutrition. Nutrition, 18:872-879.

81. Fatouros, I.G., Jamurtas, A.Z., Villiotou, V., Pouliopoulou, S., Fotinakis, P., Taxildaris, K., Deliconstantinos, G. (2004). Oxidative stress responses in older men during endurance training and detraining. Med. Sci. Sports Exerc., 36(12), 2065-2072.

82. Finaud, J., Scislowski, V., Lac, G., Durand, D., Vidalin, H., Robert, A. (2006). Antioxidant status and oxidative stress in professional rugby players: evolution throughout a season. Int. J. Sports Med., 27, 87-93.

83. Fridovich, I. (1976). Biological effects of superoxide radical. Archives of biochemistry and Biophsics, 247, 1-11.

84. Gaeini, A.A., Rahnama, N., Hamedinia, M.R. (2006). Effects of vitamin E supplementation on oxidative stress at rest and after exercise to exhaustion in athletic students. J. Sports Med. Phys. Fitness, 46(3), 458-461.

85. Galter, D., Mihm, S., Droge, W. (1994). Distinct effects of glutathione disulphide on the nuclear transcription factor kappa B and the activator protein-1. Eur. J. Biochem, 221(2), 639-648.

86. Gambelunghe, C., Rossi, R., Micheletti, A., Mariucci, G., Rufini, S. (2001). Physical exercise intensity can be related to plasma glutathione levels. J. Physiol Biochem, 57(2),9-14.

87. Gautam, S.C., Xu, Y.X., Pindolia, K.R., Janakiraman, N. Chapman, R.A. (1998). Nonselective inhibition of proliferation of transformed and nontransformed cells by the anticancer agent curcumin (diferuloylmethane). Biochem Pharmacol, 55(8),1333-1337.

88. Gerster, H. (1993). Anticarcinogenic Effect of Common Carotenoids, Internat. J. Nutr. Res., 63, 93-121.

89. Giardino, F.J. (2005). Oxygen, oxidative stress, hypoxia, and heart failure. The Journal of Clinical Investigation; 115(3), 500-508. 97.

90. Giles, N.M., Giles, G.I., Holley, J.E., Gutowski, N.J., Jacob, C. (2003). Targeting Oxidative Stress Related Diseases: Organochalcogen Catalysts as Redox Sensitizers. Biochemical Pharmocology, 66, 20212028.

91. Giovanelli, G., Buratti, S. (2009). Comparison of polyphenolic composition and antioxidant activity of wild Italian blueberries and some cultivated varieties. Food Chemistry, 112: 903-908. 
92. Goel, A., Ajaikumar, B.K., Aggarwal, B.B. (2008). Curcumin as “Curecumin” : From kitchen to clinic, Biochemical Pharmocology, 75, 787-809.

93. Goldfarb, A.H., Bloomer, R., McKenzie, M.J. (2004). Effect of microhydrin on blood lactate, protein carbonyls, and glutathione status in rats before and after aerobic exercise. Int. J. Sport Nutr. Exerc. Metab., 14(5), 550-559.

94. Goldfarb, A.H., Bloomer, R.J., McKenzie, M.J. (2005). Combined antioxidant treatment effects on blood oxidative stress after eccentric exercise. Med. Sci. Sports Exerc., 37(2),234-239.

95. Goldfarb, A.H., McIntosh, M.K., Boyer, B.T. (1996). Vitamin E attenuates myocardial oxidative stress induced by DHEA in rested and exercised rats. J. Appl Physiol, 80, 486-90.

96. Goldfarb, A.H., McKenzie, M.J., Bloomer. R.J. (2007). Gender comparisons of exercise induced oxidative stress: influence of antioxidant supplementation. Appl Physiol Nutr Metab, 32(6),1124-1131.

97. Goldfarb, A.H., Patrick, S.W., Bryer, S., You, T. (2005). Vitamin C supplementation affects oxidative-stress blood markers in response to a 30-minute run at 75\% VO2max. Int. J. Sport Nutr. Exerc. Metab, 15(3),279-290.

98. Gollnick, P.D., Bayly, W.M., Hodgson, D.R. (1986). Exercise intensity, training, diet, and lactate concentration in muscle and blood. Med. Sci. Sports Exerc., 18(3), 334-340.

99. Goto, C., Nishioka, K., Umemura, T., Jitsuiki, D., Sakagutchi, A., Kawamura, M., Chayama, K., Yoshizumi, M., Higashi, Y. (2007). Acute moderate intensity exercise induces vasodilation through an increase in nitric oxide bioavailiability in humans. Am J. Hypertens, 20(8),825-830.

100.Gönenç, S., Açıkgöz, O. (1997). Akut egzersizin lipit peroksidasyon düzeylerine etkisi. Spor Hekimliği Dergisi, 32: 155-160.

101.Grant, S., McMillan, K., Newell, J., Wood, L., Keatley, S., Simpson, D. (2002). Reproducibility of the blood lactate threshold, 4 mmol.l(-1) marker, heart rate and ratings of perceived exertion during incremental treadmill exercise in humans. Eur J. Appl Physiol, 87, 159-166.

102.Groussard, C., Rannou Bekono, F., Machefer, G., Chevanne, M., Vincent, S., Sergent, O., Cillard, J., Gratas-Delamarche, A. (2003). Changes in blood lipid peroxidation markers and antioxidants after a single sprint anaerobic exercise. Eur. J. Appl Physiol, 89(1),14-20.

103.Gutterıdge, J.M.C. (1996). Lipid peroxidation antioxidants as biomarkers of tissue damage. Clin. Chem., 41, 1819-1928. 
104.Gülçin, İ. (2002). Determination of antioxidant activity, characterization of oxidative enzymes, and investigation of some in vivo properties of nettle (Urtica dioica). PhD thesis, Atatürk University pp 45-48.

105.Güllü, E. (2007). Sedanterlerde ve Dayanıklılık Sporcularında Maksimal ve Submaksimal Egzersiz Sonrası Oluşan Oksidan Stres ve Antioksidan Düzeylerinin Karşılaştırılması. Doktora tezi, Gazi Üniversitesi, Ankara.

106.Günay, M., Tamer, K., Cicioğlu, İ. (2006). Spor fizyolojisi ve performans ölçümü. Ankara: Gazi Kitabevi.

107.Gürdöl, F., Ademoğlu, E. (2010). Biyokimya, 1.Baskı, İstanbul, Nobel Tip Kitabevleri, 829-836.

108. Güzel, N.A., Hazar, S., Erbas, D. (2007). Effects of different resistance exercise protocols on nitric oxide, lipid peroxidation and creatine kinase activity in sedentary males. J. Sport. Sci. Med., 6, 417 - 417.

109.Haliwell, B., Gutteridge, J.M.C., Cross, C.E. (1992). Free Radicals, Antioxidants and Human Disease: Where are we now? J. Lab. Clin. Med., 119, 598-620.

110. Halliwell, B. (1984). Oxygen radicals: a commonsense look at their nature and medical importance. Med. Biol., 62(2),71-77.

111. Halliwell, B. (1991). Reactive oxygen species in living systems: source, biochemistry, and role in human disease. Am J. Med., 91(3C), 14S-22S.

112. Halliwell, B., Cross, C.E. (1994). Oxygen derived species: their relation to human disease and environmental stress. Environ Health Perspect, 102(Suppl 10), 5-12.

113.Hartmann, A., Niess, A.M., Grunert-Fuchs, M., Poch, B., Speit, G. (1995). Vitamin E prevents exercise induced DNA damage. Mutat Res, 346(4),195-202.

114.Hehner, S.P., Breitkreutz, R., Shubinsky, G., Unsoeld, H., Schulze-Osthoff, K., Schmitz, M.L., Droge, W. (2000). Enhancement of T cell receptor signaling by a mild oxidative shift in the intracellular thiol pool. J. Immunol, 165(8),4319-4328.

115.Hellsten, Y., Frandsen, U., Orthenblad, N., Sjodin, B., Richter, E.A. (1997). Xanthine oxidase in human skeletal muscle following eccentric exercise: a role in inflammation. J. Physiol, 498(Pt 1),239248.

116. Hellsten, Y., Svensson, M., Sjodin, B., Smith, S., Christensen, A., Richter, E.A., Bangsbo, J. (2001). Allantoin formation and urate and glutathione exchange in human muscle during submaximal exercise. Free Radic Biol Med., 31(11),1313-1322. 
117.Henriksen, E.J., Saengsirisuwan, V. (2003). Exercise training and antioxidants: relief from oxidative stress and insulin resistance. Exerc Sport Sci Rev; 31: 79-84.

118.Hoffman, G.L., Pedersen, B.K. (1994). Exercise and the immune system; a model of the stres response. Immunology Today, 15, 382387.

119.Holloway, G.P., Bezaire, V., Heigenhauser, G.J.F., Tandon, N.N., Glatz, J.F.C., Luiken, J.J.F.P., Bonen, A., Spriet, L.L. (2006). Mitochondrial long chain fatty acid oxidation, fatty acid translocase/cd 36 content and carnitine palmitoyltransferase activity in human skeletal muscle during aerobic exercise. J. Physiol, 571(1), 201-210.

120.İkizler, M., Erkasap, N., Dernek, S., Kural, T., Kaygisiz, Z. (2007). Dietary polyphenol quercetin protects rats hearts during reperfusion: enhanced antioxidant capacity with chronic treatment. Anadolu Kardioloji Dergisi, 7, 404-410.

121.İlbey, Y.O., Özbek, E., Cekmen, M., Şimsek, A.,Tunctemur, A., Somay, A. (2009). Protective effect of curcumin in cisplatinninduced oxidative injury in rat testis: mitogen activated protein kinase and nuclear factor kappa B signaling pathways. Hum. Reprod., 24(7),1717-25.

122.İnal, M., Akyüz, F., Turgut, A., Getsfrid, W.M. (2001). Effect of aerobic and anaerobic metabolism on free radical generation swimmers. Med. Sci. Sports Exerc., 33(4),564-567.

123.İtoh, H., Ohkuwa, T., Yamazaki, Y., Shimoda, T., Wakayama, A., Tamura, S., Yamamoto, T., Sato, Y., Miyamura, M. (2000). Vitamin E supplementation attenuates leakage of enzymes following 6 successive days of running training. Int. J. Sports Med., 21(5),369-374.

124.Jackson, M.J. (2000). Exercise and oxygen radical production by muscle. In Handbook of oxidants and antioxidants in exercise Edited by: Sen CK, Packer L, Hanninen O. Amsterdam: Elsevier Science:57-68.

125.Jana, K, Samanta, P.K., Manna, I., Ghosh, P., Singh, N., Khetan, R.P., Ray, B.R. (2008). Protective effect ofsodium selenite and zinc sulfate on intensive swimming-induced testicular gamatogenic andsteroidogenic disorders in mature male rats.Appl Physiol Nutr Metab. 33: 903-14.

126.Jaruga, E., Salvioli, S., Dobrucki, J., Chrul, S., Bandorowicz-Pikula, J., Sikora, E., Franceschi, C., Cossarizza, A., Bartosz, G. (1998). Apoptosis-like, reversible changes in plasma membrane asymmetry and permeability, and transient modifications in mitochondri- 
al membrane potential induced by curcumin in rats thymocytes. FEBS Lett, 433 (3): 283-297.

127.Jenkins, R.R. (1988). Free radical chemistry. Relationship to exercise. Sports Med. 5(3):156-70.

128.Jenkins, R.R. (1993). Exercise, oxidative stress, and antioxidants: a review. Int J Sport Nutr. 1993; 3: 356-75.

129.Ji, L.L., Gomez-Cabrera, M.C., Vina, J. (2006). Exercise and hormesis: activation of cellular antioxidant signaling pathway. Ann N Y Acad Sci, 1067:425-435.

130.Ji, L.L., Stratman, F.W., Lardy, H.A. (1988). Antioxidant enzyme systems in rat liver and skeletal muscle. Influences of selenium deficiency, chronic training, and acute exercise. Arch Biochemn Biophys, 263: 150-60.

131.Jones, E.A., Shahed, A. Shoskes, D.A. (2000). Modulation of apoptotic and inflammatory genes by bioflavanoids and angiotensin II inhibition in ureteral obstruction. Urology, 56 (2): 346-351.

132.Kaikkonen, J., Kosonen, L., Nyyssonen, K., Porkkala-Sarataho, E., Salonen, R., Korpela, H., Salonen, J.T. (1998). Effect of combined coenzyme Q10 and d-alpha-tocopheryl acetate supplementation on exercise- induced lipid peroxidation and muscular damage: a placebo- controlled double-blind study in marathon runners. Free Radic Res, 29(1):85-92.

133.Kaikkonen, J., Porkkala-Sarataho, E., Tuomainen, T.P., Nyyssonen, K., Kosonen, L., Ristonmaa, U., Lakka, H.M., Salonen, R., Korpela, H., Salonen, J.T. (2002). Exhaustive exercise increases plasma/ serum total oxidation resistance in moderately trained men and women, whereas their VLDL + LDL lipoprotein fraction is more susceptible to oxidation. Scand J Clin Lab Invest, 62(8):599-607.

134.Kanaley, J.A., Ji, L.L. (1991). Antioxidant enzyme activity during prolonged exercise in amenorrheic and eumenorrheic athletes. Metabolism, 40(1):88-92.

135. Kanter, M. (1995). Free Radicals and Exercise: Effects of nutritional antioxidant supplementation. Exerc Sport Sci Rev 23:375-398.

136. Karanth, J., Kumar, R., Jeevaratnam, K. (2004). Response of antioxidant system in rats to dietary fat and physical activity. Indian J Physiol Pharmacol, 48: 446-52.

137.Kawai, Y., Shimomitsu, T., Takanami, Y., Murase, N., Katsumura, T., Maruyama, C. (2000). Vitamin E level changes in serum and red blood cells due to acute exhaustive exercise in collegiate women. J Nutr Sci Vitaminol (Tokyo), 46(3):119-124. 
138.Kawamori, T., Lubet, R., Steele, V., Kelloff, G.J., Kaskey, R.B., Rao, C.V., Reddy, B.S. (1999). Chemopreventive effect of curcumin, a naturally occuring anti-inflammatory agent, during the promotion/ progression stages of colon cancer. Cancer Res, 59 (3): 597-601.

139. Kayatekin, B.M., Gonenc, S., Acikgoz, O., Uysal, N., Dayi, A. (2002). Effects of sprint exercise on oxidative stress in skeletal muscle and liver. Eur J Appl Physiol, 87(2):141-144.

140.Khopde, S.M., Priyadarsini, K.I., Guha, S.N., Satav, J.G., Venkatesan, P., Rao, M.N. (2000). Inhibition of radiation-induced lipid peroxidation by tetrahydrocurcumin: possible mechanisms by pulse radiolysis. Biosci Biotechnol Biochem, 64: 503-9.

141.Kim, H.T. (2005). Effect of the joint administration of selenium and vitamin $\mathrm{E}$ in combination with regular aerobic exercise on markers of lipid peroxidation and glutathione peroxidase in diabetic rats. Int J Sport Nutr Exerc Metab, 15: 266-78.

142.Kingsley, M.I., Kilduff, L.P., McEneny, J., Dietzig, R.E., Benton, D. (2006). Phosphatidylserine supplementation and recovery following downhill running. Med Sci Sports Exerc, 38(9):1617-1625.

143.Kirkendail, D.T. (1990). Mechanisms of peripheral fatiqu. Med. Sci. Sports. Exerc., 22(4): 444-449.

144.Knez, W.L., Coombes, J.S., Jenkins, D.G. (2006). Ultra endurance exercise and oxidative damage: implications for cardiovascular health. Sports Med, 36(5):429-441.

145.Knez, W.L., Jenkins, D.G., Coombes, J.S. (2007). Oxidative stress in half and full Ironman triathletes. Med Sci Sports Exerc, 39(2):283288.

146.Koesterer, T.J., Dodd, S.L., Powers, S. (2002). Increased antioxidant capacity does not attenuate muscle atrophy caused by unweighting. J Appl Physiol, 93: 1959-1965.

147.Kretzschmar, M., Muller, D., Hubscher, J., Marin, E., Klinger, W. (1991). Influence of aging, training and acute physical exercise on plasma glutathione and lipid peroxides in man. Int J Sports Med, (2):218-222.

148.Laires, M.J., Madeira, F., Sergio, J., Colaco, C., Vaz, C., Felisberto, G.M., Neto, I., Breitenfeld, L., Bicho, M., Manso, C. (1993). Preliminary study of the relationship between plasma and erythrocyte magnesium variations and some circulating pro-oxidant and antioxidant indices in a standardized physical effort. Magnes Res, 6(3):233-238.

149.Leaf, D.A. (1997). The effect of exercise intensity on lipid peroxidation. Med. Sci. Sports Exerc,29: 1106-1109. 
150.Lee, I.M., Hsieh, C.C., Paffenbarger, R.S . (1995). Jr: Exercise intensity and longevity in men. The Harvard Alumni Health Study. JAMA, 273(15):1179-1184.

151.Leeuwenburgh, C., Heinecke, J.W. (2001). Oxidative stress and antioxidants in exercise. Curr Med Chem, 8: 829-38.

152.Liu, J., Yeo, H.C., Overvik-Douki, E., Hagen, T., Doniger, S.J., Chyu, D.W., Brooks, G.A., Ames, B.N. (2000). Chronically and acutely exercised rats: biomarkers of oxidative stress and endogenous antioxidants. J Appl Physiol, 89(1):21-28.

153.Luck, H. (1955). Catalase. In: Bergmeyer HU, editor. Methods in Analysis. London: Academy Press.

154.Lwow, F., Dunajska, K., Tworowska, U., Jedrzejuk, D., Laczmanski, L., Milewicz, A., Szmigiero, L. (2007). Post exercise oxidative stress and obesity in postmenopausal women: the role of beta 3-adrenergic receptor polymorphism. Gynecol Endocrinol, 23(10):597-603.

155.Magalhaes, J., Ferreira, R., Marques, F., Olivera, E., Soares, J., Ascensao, A. (2007). Indoor climbing elicits plasma oxidative stress. Med Sci Sports Exerc, 39(6):955-963.

156. Maheshwari, R.K., Singh, A.K., Gaddipati, J., Srimal, R.C. (2006). Multiple biological activities of curcumin: A short review. Life Sciences, 78: 2081-2087.

157.Majithiya, J.B., Balaraman, R., Gridhar, R., Yadav, M.R. (2005). Effect of bis[curcumino] oxovanadium complex on non-diabetic and streptozotocin-induced diabetic rats. J Trace Elem Med Biol, 18 (3): 211-217.

158.Margaritis, I., Palazzetti, S., Rousseau, A.S., Richard, M.J., Favier, A. (2003). Antioxidant supplementation and tapering exercise improve exercise induced antioxidant response. J Am Coll Nutr, 22(2):147-156.

159.Margaritis, I., Tessier, F., Richard, M.J., Marconnet, P. (1997). No evidence of oxidative stress after a triathlon race in highly trained competitors. Int J Sports Med, 18(3):186-190.

160.Marzatico, F., Pansarasa, O., Bertorelli, L., Somenzini, L., Della Valle, G. (1997). Blood free radical antioxidant enzymes and lipid peroxides following long distance and lactacidemic performances in highly trained aerobic and sprint athletes. J. Sports Med. Phys. Fitness, 37(4):235-239.

161.Mastaloudis, A., Morrow, J.D., Hopkins, D.W., Devaraj, S., Traber, M.G. (2004). Antioxidant supplementation prevents exercise-induced lipid peroxidation, but not inflammation, in ultramarathon runners. Free Radic Biol Med, 36(10):1329-1341. 
162.Mastaloudis, A., Yu, T.W., O’Donnell, R.P., Frei, B., Dashwood, R.H., Traber, M.G. (2004). Endurance exercise results in DNA damage as detected by the comet assay. Free Radic Biol Med, 36(8):966-975.

163.Maughan, R.J., Donnelly, A.E., Gleeson, M., Whiting, P.H., Walker, K.A., Clough, P.J. (1989). Delayed onset muscle damage and lipid peroxidation in man after a downhill run. Muscle Nerve, 12(4):332336.

164.McAnulty, S,R,, McAnulty, L.S., Nieman, D.C., Morrow, J.D., Utter, A.C., Dumke, C.L. (2005). Effect of resistance exercise and carbohydrate ingestion on oxidative stress. Free Radic Res, 39(11):12191224.

165.McAnulty, S., McAnulty, L., Nieman, D., Morrow, J., Dumke, C., Utter, A. (2007). Carbohydrate effect: hormone and oxidative changes. Int J Sports Med, 28(11):921-927.

166.McAnulty, S.R., McAnulty, L.S., Nieman, D.C., Morrow, J.D., Shooter, L.A., Holmes, S., Heward, C., Henson, D.A. (2005). Effect of alpha-tocopherol supplementation on plasma homocysteine and oxidative stress in highly trained athletes before and after exhaustive exercise. J Nutr Biochem, 16(9):530-537.

167.McAnulty, S.R., Owens, J.T., McAnulty, L.S., Nieman, D.C., Morrow, J.D., Dumke, C.L., Milne, G.L. (2007). Ibuprofen use during extreme exercise: effects on oxidative stress and PGE2. Med Sci Sports Exerc, 39(7):1075-1079.

168.McCully, K.K., Faulkner, J.A. (1985). Injury to skeletal muscle fibers of mice following lengthening contractions. J Appl Physiol, 59(1):119-126.

169.McIntyre, M., Bohr, D.F., Dominiczak, A.F. (1999). Endothelial Function in Hypertension: The Role of Superoxide Anion. Hypertension; 34: 539-545.

170.Medved, I., Brown, M.J., Bjorksten, A.R., Murphy, K.T., Petersen, A.C., Sostaric, S., Gong, X., McKenna, M.J. (2004). N-acetylcysteine enhances muscle cysteine and glutathione availability and attenuates fatigue during prolonged exercise in endurance-trained individuals. J Appl Physiol, 97(4):1477-1485.

171. Meisler, A., Anderson, M.E. (1983). Glutathione. Ann. Rev. Biochem. 52, 711-60.

172.Mena, P., Maynar, M., Gutierrez, J.M., Maynar, J.,Timon, J., Campillo, J.E. (1991). Erythrocyte free radical scavenger enzymes in bicycle professional racers, adaptation to training. Int. J. Sports Med,12: 563-566. 
173.Menon, V.P., Sudheer, A.R. (2007). Antioxidant and ant1-1nflammatory properties of curcumin. Adv. Exp. Med. Biol. 595: 103-125.

174. Mercan, U. (2004). Toksikolojide Serbest Radikallerin Önemi. Yüzüncü Yıl Üniversitesi Veterinerlik Fakültesi Dergisi;15: 91-6.

175.Metin, G., Gumustas, M.K., Uslu, E., Belce, A., Kayserilioglu, A. (2003). Effect of regular training on plasma thiols, malondialdehyde and carnitine concentrations in young soccer players. Chin J Physiol, 46(1):35-39.

176.Meydani, M., Evans, W.J., Handelman, G., Biddle, L., Fielding, R.A., Meydani, S.N., Burrill, J., Fiatarone, M.A., Blumberg, J.B., Cannon, J.G. (1993). Protective effect of vitamin E on exercise induced oxidative damage in young and older adults. Am J Physiol, 264(5 Pt 2):R992-8.

177.Michailidis, Y., Jamurtas, A.Z., Nikolaidis, M.G., Fatouros, I.G., Koutedakis, Y., Papassotiriou, I., Kouretas, D. (2007). Sampling time is crucial for measurement of aerobic exercise-induced oxidative stress. Med Sci Sports Exerc, 39(7):1107-1113.

178.Miller, D.M., Buettner, G.R., Aust, S.D. (1990). Transition metals as catalysts of "autoxidation" reactions. Free Radic Biol Med, 8(1):95108.

179.Montgomery, R., Dryer, R., Conway, T., Spector, A. (2000). Biyokimya-Olgu Sunumlu Yaklaşım. 6. Baskıdan Çeviri (Atlan N. Çeviri Editörü). Ankara, Palme Yayıncılık.

180.Morillas-Ruiz, J,. Zafrilla, P., Almar, M., Cuevas, M.J., Lopez, F.J., Abellan, P., Villegas, J.A., Gonzalez-Gallego, J. (2005).The effects of an antioxidant-supplemented beverage on exercise-induced oxidative stress: results from a placebo controlled double blind study in cyclists. Eur J Appl Physiol, 95(5-6):543-549.

181.Nelson, D.L., Cox, M.M. (2005). Biyokimyanın İlkeleri. 3. Baskıdan Çeviri (Kılıç N. Çeviri Editörü). Ankara: Palme Yayıncılık.

182.Niess, A.M., Simon, P. (2007). Response and adaptation of skeletal muscle to exercise the role of reactive oxygen species. Front Biosci, 12:4826-4838.

183.Nikolaidis, M.G., Kyparos, A., Hadziioannou, M., Panou, N., Samaras, L., Jamurtas, A.Z., Kouretas, D. (2007). Acute exercise markedly increases blood oxidative stress in boys and girls. Appl Physiol Nutr Metab, 32(2):197-205.

184.Nikolaidis, M.G., Paschalis, V., Giakas, G., Fatouros, I.G., Koutedakis, Y., Kouretas, D., Jamurtas, A.Z. (2007). Decreased blood oxidative stress after repeated muscle-damaging exercise. Med Sci Sports Exerc, 39(7):1080-1089. 
185.Nseir, W., Shalata, A., Marmor, A., Assy, N. (2011). Mechanisms linking nonalcoholic fatty liver disease with coronary artery disease. Dig Dis Sci. 56: 3439-3449.

186.Oh-ishi, S., Heinecke, J.W., Ookawara, T., Miyazaki, H., Haga, S., Radak, Z., Kizaki, T., Ohno, H. (2000). Role of Lipid and Lipoprotein Oxidation. In Free Radicals in Exercise and Aging Edited by: Radak Z. Champaign, IL: Human Kinetics :211-258.

187.Öner-İyidoğan, Y., Koçak, H., Seyidhanoğlu, M., Gürdöl, F., Gülçubuk, A., Yildirim, F., Çevik, A., Uysal, M. (2013). Curcumin prevents liver fat accumulation and serum fetuin-A increase in rats fed a high-fat diet. J Physiol Biochem. 69: 677-686.

188.Öztürk, A., Baltac1, A.K., Mogulkoç, R., Öztekin, A., Sivrikaya, A., Kurtoglu, E., Kul, A. (2003). Effects of zinc deficiency and supplementation on malondialdehyde and glutathione levels in blood and tissue of rats performing swimming exercise. Biological Trace Element Research, 94: 157-166.

189.Palazzetti, S., Richard, M.J., Favier, A., Margaritis, I. (2003). Overloaded training increases exercise induced oxidative stress and damage. Can J Appl Physiol, 28(4):588-604.

190.Palazzetti, S., Rousseau, A.S., Richard, M.J., Favier, A., Margaritis, I. (2004). Antioxidant supplementation preserves antioxidant response in physical training and low antioxidant intake. Br J Nutr, 91(1):91-100.

191.Palmer, F.M., Nieman, D.C., Henson, D.A., McAnulty, S.R., McAnulty, L., Swick, N.S., Utter, A.C., Vinci, D.M., Morrow, J.D. (2003). Influence of vitamin $C$ supplementation on oxidative and salivary IgA changes following an ultramarathon. Eur J Appl Physiol, 89(1):100-107.

192.Paschalis, V., Nikolaidis, M.G., Fatouros, I.G., Giakas, G., Koutedakis, Y., Karatzaferi, C., Kouretas, D., Jamurtas, A.Z. (2007). Uniform and prolonged changes in blood oxidative stress after muscle-damaging exercise. In Vivo, 21(5):877-883.

193.Phan, T.T., See, P., Lee, S.T., Chan, S.Y. (2001). Protective effects of curcumin against oxidative damage on skin cells in vitro: its implication for wound healing. J Trauma, 51 (5): 927-931.

194.Pincemail, J., Camus, G.,Roesgen, A., Dreezen, E., Bertrand, Y., Lismonde, M., Deby-Dupont, G., Deby, C.(1990). Exercise induces pentane production and neutrophil activation in humans. Effect of propranolol. Eur J Appl Physiol Occup Physiol, 61(3-4):319-322.

195.Powers, S.K., Crıswell, D., Lawler, J., Ji, L.L., Martın, D., Herb, R.A., Dudley, G. (1994). Influence of exercise and fiber type on antioxi- 
dant enzyme activity in rat skeletal muscle, Am J Physiol, 266: 37580 .

196.Powers, S.K., Ji, L.L., Leeuwenburgh, C. (1999). Exercise training induced alterations in skeletal muscleb antioxidant capacity: a brief review. Med Sci Sports Exerc,31: 987-997.

197.Prasad, K., Karla, J., Chan, P., Chaudhary, A.K. (1989). Effect of Oxygen Free Radicals on Cardiovascular Function at Organ and Cellular Levels. American Heart Journal, 117: 1196-1202.

198.Quindry, J.C., Stone, W.L., King, J., Broeder, C.E. (2003). The effects of acute exercise on neutrophils and plasma oxidative stress. Med Sci Sports Exerc, 35: 1139-45.

199.Rahnama, N., Gaeini, A.A., Hamedinia, M.R. (2007). Oxidative stress responses in physical education students during 8 weeks aerobic training. J Sports Med Phys Fitness, 47(1):119-123.

200. Rasmussen, H.B., Christensen, S.B., Kvist, L.P., Karazmi, A. (2000). A simple and efficient separation of curcumins, the antiprotozoal constituents of curcuma longa. Planta Med, 66 (4): 396-398.

201.Reddy, A.C., Lokesh, B.R. (1994). Studies on the inhibitory effects of curcumin and eugenol on the formation of reactive oxygen species and the oxidation of ferrous iron. Mol Cell Biochem, 137:1-8.

202.Reddy, K.V., Kumar, T.C., Prasad, M., Reddanna, P. (1998). Pulmonary lipid peroxidation and antioxidant defenses during exhaustive physical exercise: the role of vitamin E and selenium. Nutrition,14: 448-451.

203. Reid, M.B. (2001). Nitric oxide, reactive oxygen species, and skeletal muscle contraction. Med Sci Sports Exerc, 33(3):371-376.

204.Rietjens, S.J., Beelen, M., Koopman, R., Van Loon, L.J., Bast, A., Haenen, G.R. (2007). A single session of resistance exercise induces oxidative damage in untrained men. Med Sci Sports Exerc, 39(12):2145-2151.

205.Roberts, L.J. 2nd., Oates, J.A., Linton, M.F., Fazio, S., Meador, B.P., Gross, M.D., Shyr, Y., Morrow, J.D. (2007). The relationship between dose of vitamin $\mathrm{E}$ and suppression of oxidative stress in humans. Free Radic Biol Med, 43(10):1388-1393.

206. Robinson, T.P., Ehlers, T., Hubbard, IV., R.B., Bai, X., Arbiser, J.L., Goldsmith, D.J., Bowen, J.P. (2003). Design, synhesis, and biological evaluation of angiogenesis inhibitors: aromatic enone and dienone analogues of curcumin. Bioorg Med Chem Lett, 13 (1): 115-117.

207.Rodriguez, M.C., Rosenfeld, J., Tarnopolsky, M.A. (2003). Plasma malondialdehyde increases transiently after ischemic forearm exercise. Med Sci Sports Exerc, 35(11):1859-1865. 
208. Ross, S.M. (2007). Coenzyme q10: ubiquinone: a potent antioxidant and key energy facilitator for the heart. Holist Nurs Pract, 21(4):213-214.

209.Rush, J.W., Sandiford, S.D. (2003). Plasma glutathione peroxidase in healthy young adults: influence of gender and physical activity. Clin Biochem, 36(5):345-351.

210.Sacheck, J.M., Cannon, J.G., Hamada, K., Vannier, E., Blumberg, J.B., Roubenoff, R. (2006). Age related loss of associations between acute exercise induced IL-6 and oxidative stress. Am J Physiol Endocrinol Metab, 291(2):E340-9.

211.Sacheck, J.M., Decker, E.A., Clarkson, P.M. (2000). The effect of diet on vitamin $\mathrm{E}$ intake and oxidative stress in response to acute exercise in female athletes. Eur J Appl Physiol, 83(1):40-46.

212.Sacheck, J.M., Milbury, P.E., Cannon, J.G., Roubenoff, R., Blumberg, J.B. (2003). Effect of vitamin E and eccentric exercise on selected biomarkers of oxidative stress in young and elderly men. Free Radic Biol Med, 34(12):1575-1588.

213.Sahlin, K., Cizinsky, S., Warholm, M., Hoberg, J. (1992). Repetitive static muscle contractions in humans - a trigger of metabolic and oxidative stress? Eur. J. Appl Physiol Occup Physiol, 64(3):228-236.

214.Sahlin, K., Ekberg, K., Cizinsky, S. (1991). Changes in plasma hypoxanthine and free radical markers during exercise in man. Acta Physiologica Scandinavica, 141: 275-281.

215.Sanchez-Quesada, J.L., Homs-Serradesanferm, R., Serrat-Serrat, J., Serra- Grima, J.R., Gonzalez-Sastre, F., Ordonez-Llanos, J. (1995). Increase of LDL susceptibility to oxidation occurring after intense, long duration aerobic exercise. Atherosclerosis, 118(2):297-305.

216.Sastre, J., Asensi, M., Gasco, E., Pallardo, F.V., Ferrero, J.A., Furukawa, T., Vina, J.(1992). Exhaustive physical exercise causes oxidation of glutathione status in blood: prevention by antioxidant administration. Am J Physiol, 263(5 Pt 2):R992-5.

217.Schiffl, C., Zieres, C., Zankl, H. (1997). Exhaustive physical exercise increases frequency of micronuclei. Mutat Res, 389(2-3):243-246.

218.Schippinger, G., Wonisch, W., Abuja, P.M., Fankhauser, F., Winklhofer- Roob, B.M., Halwachs, G. (2002). Lipid peroxidation and antioxidant status in professional American football players during competition. Eur J Clin Invest, 32(9):686-692.

219.Schirmer, R.H., Krauth-Siegel, R.L., Schulz, G.E. (1989). Glutathione Reducase, New York, John Wiley and Sons Press.pp. 553-596.

220.Schmid, E., El Benna, J., Galter, D., Klein, G., Droge, W. (1998). Redox priming of the insulin receptor beta chain associated with 
altered tyrosine kinase activity and insulin responsiveness in the absence of tyrosine autophosphorylation. Faseb J, 12(10):863-870.

221.Schroder, H., Navarro, E., Mora, J., Galiano, D., Tramullas, A. (2001). Effects of alpha tocopherol, beta carotene and ascorbic acid on oxidative, hormonal and enzymatic exercise stress markers in habitual training activity of professional basketball players. Eur J Nutr, 40(4):178-184.

222.Selçuk, M. (2003). Sedanterler İle Kuzey Disiplini Yapan Antrene Bireylerde Programlı Aerobik ve Anaerobik Egzersizlerin Bazı Antioksidan Profiller Üzerine Etkilerinin Araştırılması. Doktora tezi Yüzüncü Yıl Üniversitesi, Van.

223.Seshiah, P.N., Weber, D.S., Rocic, P., Valppu, L., Taniyama, Y., Griendling, K.K. (2002). Angiotension II Stimulation of NADPH Oxidase Activity: Upstream Mediators. Circulation Research, 91: 406-413.

224.Sharma, R.A., Gescher, A.J., Steward, W.P. (2005). Curcumin: The story so far European Journal of Cancer; 41: 1955-1968.

225.Shim, J.S., Kim, D.H., Jung, H.J., Kim, J.H., Lim, D., Lee, S.K., Kim, K.W., Ahn, J.W.,Yoo, J.S., Rho, J.R., Shin, J., Kwon, H.J. (2002). Hydrazinocurcumin, a novel synthetic curcumin derivative, is a potent inhibitor of endothelial cell proliferation. Bioorg Med Chem, 10 (9): 2987-2992.

226.Sidhu, G.S., Singh, A.K., Thaloor, D., Banaudha, K.K., Patnaik, G.K., Srimal, R.C., Maheshwari, R.K. (1998). Enhancement of wound healing by curcumin in animals. Wound Repair Regen, 6 (2): 167-177.

227.Sies, H., Stahl, W., Sevanian, A. (2005). Nutritional, dietary and postprandial oxidative stress. J Nutr, 135(5):969-972.

228.Singh, S.V., Hu, X., Srivastava, S.K., Singh, M., Xia, H., Orchard, J.L., Zaren, H.A. (1998). Mechanism inhibition of benzo[a]pyrene-induced forestomach cancer in mice dietary curcumin. Carcinogenesis, 19 (8): 1357-1360.

229.Smith, J.E.W., Pirner, M., Zachwieja Jeffrey J.F.A.C.S.M. (2011). Quercetin Lowers Blood Lactate Response During Progressively Intense Exercise. Medicine Science in Sports Exercis, 43(5): 430.

230.Sönmez, G.T. (2002). Egzersiz ve Spor Fizyolojisi, Ankara. Ata Ofset Matbaacilik.

231.Sreejayan, N., Rao, M.N. (1996). Free radical scavenging activity of curcuminoids. Arzneimittelforschung, 46: 169-171.

232.Sreejayan, Rao, M.N. (1997). Nitric oxide scavenging by curcuminoids. J Pharm Pharmacol, 49:105-7. 
233.Srivastava, S.K., Beutler, E. (1970). Glutathione metabolism of the erythrocyte. The enzymic cleavage of glutathione-haemoglobin preparations by glutathione reductase, Biochem J;119: 353-357.

234.Steinberg, J.G., Ba, A., Bregeon, F., Delliaux, S., Jammes, Y. (2007). Cytokine and oxidative responses to maximal cycling exercise in sedentary subjects. Med Sci Sports Exerc, 39(6):964-968.

235.Steinberg, J.G., Delliaux, S., Jammes, Y. (2006). Reliability of different blood indices to explore the oxidative stress in response to maximal cycling and static exercises. Clin Physiol Funct Imaging, 26(2):106-112.

236.Subramanian, M., Sreejayan Rao M.N., Devasagayam, T.P., Singh, B.B. (1994). Diminution of singlet oxygen-induced DNA damage by curcumin and related antioxidants. Mutat Res.,311: 249-55.

237.Su-juan, C., Hai-ying, L., Zheng-ying, X. (2007). Effect of quercetin on hemoglobin and blood biochemical indexes in rats following exhausted exercise. Journal of Clinical Rehabilitative Tissue Engineering Research, 11 (37); 7468-7469.

238.Sumida, S., Doi, T., Sakurai, M., Yoshioka, Y., Okamura, K. (1997). Effect of a single bout of exercise and beta-carotene supplementation on the urinary excretion of 8-hydroxy-deoxyguanosine in humans. Free Radic Res, 27(6):607-618.

239.Sumida, S., Tanaka, K., Kitao, H., Nakadomo, F. (1989). Exercise induced lipid peroxidation and leakage of enzymes before and after vitamin E supplementation. Int J Biochem, 21(8):835-838.

240.Sun, Y., Oberley L.W., Li, Y. (1988). A Simple Method for Clinical Assay of Superoxide Dismutase. Clin Chem, 34: 497-500.

241.Surmen-Gur, E., Ozturk, E., Gur, H., Punduk, Z., Tuncel, P. (1999). Effect of vitamin E supplementation on post exercise plasma lipid peroxidation and blood antioxidant status in smokers: with special reference to haemoconcentration effect. Eur J Appl Physiol Occup Physiol, 79(6):472-478.

242.Swarnakar, S., Gangulky, G., Kundu, P., Banerjee, A.Maity, P., Sharma, A.V. (2005). Curcumin regulates expression and activity of matrix metalloproteinases 9 and 2 during prevention and healing of indomethacin-induced gastric ulcer. J Biol Chem, 280 (10): 94099415.

243.Tamer, L., Polat, G., Eskandari, G., Ercan, B. (2000). Serbest Radikaller. MEÜ Tıp Fakültesi Dergisi 1(1): 52-58.

244.Tauler, P., Aguilo, A., Gimeno, I., Fuentespina, E., Tur, J.A., Pons, A. (2006). Response of blood cell antioxidant enzyme defences to an- 
tioxidant diet supplementation and to intense exercise. Eur J Nutr, 45(4):187-195.

245.Tauler, P., Sureda, A., Cases, N., Aguilo, A., Rodriguez-Marroyo, J.A., Villa, G., Tur, J.A., Pons, A. (2006). Increased lymphocyte antioxidant defences in response to exhaustive exercise do not prevent oxidative damage. J Nutr Biochem, 17(10):665-671.

246.Tessier, F., Hida, H., Favier, A., Marconnet, P. (1995). Muscle GSHPx activity after prolonged exercise, training, and selenium supplementation. Biol Trace Elem Res, 47: 279-85.

247.Thaloor, D., Singh, A.K., Sidhu, G.S., Prasad, P.V., Kleinman, H.K., Maheshwari, R.K. (1998). Inhibition og angiogenic differentiation of human umbilical vein endothelial cells by curcumin. Cell Growth Differ, 9 (4): 305-312.

248. Thiyagarajan, M., Sharma, S.S. (2004). Neuroprotective effect of curcumin in middle cerebral artery occlusion induced focal cerebral ischemia in rats. Life Sci., 74 (8): 969-985.

249.Thomas, C., Perrey, S., Ben Saad, H., Delage, M., Dupuy, A.M., Cristol, J.P., Mercier, J. (2007). Effects of a supplementation during exercise and recovery. Int J Sports Med, 28(8):703-712.

250.Thompson, D., Williams, C., Garcia-Roves, P., McGregor, S.J., McArdle, F., Jackson. M.J. (2003). Post exercise vitamin C supplementation and recovery from demanding exercise. Eur J Appl Physiol, 89(3-4):393-400.

251.Thresiamma, K.C., George, J., Kuttan, R. (1998). Protective effect of curcumin, ellagic acid and bixin on radiation induced genotoxicity. J. Exp. Clin. Cancer Res.,17: 431-4.

252.Touitou, Y. (2001). Human aging and melatonin. Clinical Relevance, Experimental Gerontology, 36: 1083-1100.

253.Tsai, K., Hsu, T.G., Hsu, K.M., Cheng, H., Liu, T.Y., Hsu, C.F., Kong, C.W. (2001). Oxidative DNA damage in human peripheral leukocytes induced by massive aerobic exercise. Free Radic Biol Med, 31(11):1465-1472.

254.Turunen, M., Olsson, J. Dallner, G. (2004). "Metabolism and function of coenzyme Q", Biochimica et Biophysica Acta (BBA), Biomembranes; 1660(1-2): 171-199.

255.Urso, M.L., Clarkson, P.M. (2003). Oxidative stress, exercise andantioxidant supplementation. Toxicology, 189: 41-54.

256.Valko, M., Leibfritz, D., Moncol, J., Cronin, M.T., Mazur, M., Telser, J. (2007). Free radicals and antioxidants in normal physiological functions and human disease. Int J Biochem Cell Biol, 39(1):44-84. 
257.Varadkar, P., Dubey, P., Krishna, M., Verma, N. (2001). Modulation of radiation-induced protein kinase $\mathrm{C}$ activity by phenolics. J. Radiol Prot, 21: 361-70.

258. Vasankari, T., Kujala, U., Heinonen, O., Kapanen, J., Ahotupa, M. (1995). Measurement of serum lipid peroxidation during exercise using three different methods: diene conjugation, thiobarbituric acid reactive material and fluorescent chromolipids. Clin Chim Acta, 234(1-2):63-69.

259. Veera Reddy, K., Charles Kumar, T., Prasad, M., Reddanna, P. (1992). Exercise induced oxidant stress in the lung tissue: role of dietary supplementation of vitamin $\mathrm{E}$ and selenium. Biochem Int., 26: 863-71.

260. Venkatesan, N., Punithavathi, V., Chandrakasan, G. (1997). Curcumin protects bleomycin-induced lung injury in rats. Life Sci., 61(6):51-8.

261.Vider, J., Lehtmaa, J., Kullisaar, T., Vihalemm, T., Zilmer, K., Kairane, C., Landor, A., Karu, T., Zilmer, M. (2001). Acute immune response in respect to exercise induced oxidative stress. Pathophysiology, 7(4):263-270.

262.Vina, J., Gimeno, A., Sastre, J., Desco, C., Asensi, M., Pallardo, F.V., Cuesta, A., Ferrero, J.A., Terada, L.S., Repine, J.E. (2000). Mechanism of free radical production in exhaustive exercise in humans and rats; role of xanthine oxidase and protection by allopurinol. IUBMB Life, 49(6):539-544.

263.Vincent, H.K., Morgan, J.W., Vincent, K.R. (2004). Obesity exacerbates oxidative stress levels after acute exercise. Med Sci Sports Exerc, 36(5):772-779.

264. Vollaard, N.B., Shearman, J.P., Cooper, C.E. (2005). Exercise-induced oxidative stress: myths, realities and physiological relevance. Sports Med, 35(12):1045-1062.

265.Waring, W.S., Convery, A., Mishra, V., Shenkin, A., Webb, D.J., Maxwell, S.R. (2003). Uric acid reduces exercise-induced oxidative stress in healthy adults. Clin Sci (Lond), 105(4):425-430.

266. Watson, T.A., Callister, R., Taylor, R.D., Sibbritt, D.W., MacDonald-Wicks, L.K., Garg, M.L. (2005). Antioxidant restriction and oxidative stress in short duration exhaustive exercise. Med Sci Sports Exerc, 37(1):63-71.

267.Wei, Y.H., Pang, C.Y. (2005). The Role of Mitocondria in human aging process. Biotech International, 17: 8-13.

268. Whaley, M.H. (2005). ACSM's Guidelines for Exercise Testing and Prescription. 7th edition. 
269.Woods, J.R., Plessinger, M.A., Miller, R.K. (2001). Vitamins C and E: Missing Links in Preventing Premature Rupture of Membranes. American Journal of Obstetrics and Gynecology, 185: 5-10.

270. Yalçın, A.S. (1998). Antioksidanlar. Klinik Gelişim, 11: 342-46.

271. Yamada, M., Suzuki, K., Kudo, S., Totsuka, M., Simoyama, T., Nakaji, S., Sugawara, K. (2000). Effect of exhaustive exercise on human neutrophils in athletes. Luminescence, 15(1):15-20.

272. Yıldırım , N.C., Yürekli M. (2010). The effect of adrenomedullin and cold stres on interleukin-6 levels in som erat tissues. Clin Exp Immunol. 161(1):171-5.

273. Yilmaz, S., Ozan, S. (2003). Meme Kanserli Hastalarda Lipid Peroksidasyonu ve Bazı Enzim Aktiviteleri Arasındaki İlişki. Türk Biyokimya Dergisi. 28 (4): 252- 256.

274. You, T., Goldfarb, A.H., Bloomer, R.J., Nguyen, L., Sha, X., McKenzie, M.J. (2005). Oxidative stress response in normal and antioxidant supplemented rats to a downhill run: changes in blood and skeletal muscles. Can J Appl Physiol, 30(6):677-689.

275. Zergeroğlu, A.M., Ersöz, G., Yavuzer, S. (1997). Dayanıklılık Antrenmanlarında Antioksidan Savunma, Hacettepe Üniversitesi Spor Bilimleri Dergisi, (8), 4, 25-32.

276. Zergeroğlu, A.M., Yavuzer, S. (1997). Supramaksimal Egzersizin Eritrosit Antioksidan Enzimler Üzerine Etkisi, Spor Bilimleri Dergisi, (8)4, 13-24.

277. Zhao, J., Zhao, Y., Zheng, W., Lu, Y., Feng, G., Yu, S. (2008). Neuroprotective effect of curcumin on transient focal cerebral ischemia in rats. Brain Res., 1229:224-32.

278. Zima, T., Crkovska, J., Merta, M., Stipek, S., Nemecek, K., Tesar, V. (1995). Activity of the Antioxidant Enzymes, Glutathione Peroxidase, on Autosomal Dominant 54 polycyctic kidney disease patient. Biochemical Molecular Biology International, 35(4): 699-704.

279. Ceylan, H.I., Saygin. O., and Ozel Turkcu, U., (2020). Obezite, aerobik egzersiz ve sirkadiyen ritim iliskisi: asprosin, spexin, lipocalin-2 ve insulin hormonu uzerine yapilan bir arastirma. 3rd ed. Ankara: Gece Kitapligi.

280.Ceylan, H. İ., İrez, G. B., \& Saygın, Ö. (2014). Examining of the effects of aerobic dance and step dance exercises on some hematological parameters and blood lipids. Journal of Human Sciences, 11(2), 980-991.

281.Özcan, R., İrez, G. B., Saygın, Ö., \& Ceylan, H. İ. (2018). Aqua-pilates exercises improves some physical fitness parameters of healthy 
young women. Journal of Physical Education \& Sports Science/Beden Egitimi ve Spor Bilimleri Dergisi, 12(3)-160-175

282.Saygın, Ö., Ceylan, H. İ., \& Günay, A. R. (2018). Time of day effect on repeated sprint ability, aerobic capacity and physiological responses in team-sport athletes. International Journal of Sport Culture and Science, 6(4), 467-484.

283.İbrahim CAN, Aras Beka YAŞAR, Serdar BAYRAKDAROĞLU, Beyza YILDIZ. "Fitness Profiling in Women Soccer: Performance Characteristics of Elite Turkish Women Soccer Players", Turkish Journal of Sport and Exercise, 2019; 21(1): 78-90

284.Serdar BAYRAKDAROĞLU, İbrahim CAN. "Anaerobic Power, Lower-Body Strength Characteristic and Some Kinetics and Kinematics During Loaded-Squat Jump Movement in Turkish National Boxers and Kickboxers", Archieve of Budo Science of Martial Arts and Extreme Sports, 2018; 14(1): 153-159.

285.Tekin, A., Tekin, G., Altay, B., Çalışır, M., Bayrakdaroğlu, S. (2015). Düzenli aerobik egzersiz programının üniversiteli obez kız öğrencilerin fiziksel, motorik ve psiko-sosyal parametrelerine etkisi. Spor ve Performans Araştırmaları Dergisi, 6 (1), 19-29. 